\title{
Enhancement of phosphorus storage capacity of sediments by coastal wetland restoration, Yellow River Delta, China
}

\author{
Gang Xu ${ }^{\mathrm{a}, \mathrm{b}, *, 1}$, Jiawei Song ${ }^{\mathrm{b}, \mathrm{c}, 1}$, Yang Zhang ${ }^{\mathrm{b}, \mathrm{c}}$, Yingchun $\mathrm{Lv}^{\mathrm{a}, \mathrm{b}}$, Guangxuan $\operatorname{Han}^{\mathrm{b}, * *}$

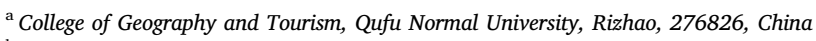 \\ ${ }^{\mathrm{b}}$ Yantai Institute of Coastal Zone Research, Chinese Academy of Sciences, Yantai, 264003, China \\ ${ }^{\mathrm{c}}$ University of Chinese Academy of Sciences, Beijing, 100049, China
}

\section{A R T I C L E I N F O}

\section{Keywords:}

Yellow river delta

Phosphorus storage capacity

Degree of phosphorus saturation

Eutrophication risk index

\begin{abstract}
A B S T R A C T:
Un-restored $\left(R_{0}\right)$ and restored (in $2006\left(R_{2006}\right)$ and in 2002, $\left(R_{2002}\right)$ ) coastal wetlands were selected to study phosphorus (P) storage capacity and the risk of $\mathrm{P}$ loss in the Yellow River Delta (YRD). The results showed that the maximum $P$ sorption capacity $\left(Q_{\max }\right)$ in the wetland sediments varied between $201.8-1168.6 \mathrm{mg} \mathrm{kg}^{-1}$; the average value was $576.2 \mathrm{mg} \mathrm{kg}^{-1}$. $\mathrm{Q}_{\max }$ increased with increasing time since restoration $\left(\mathrm{R}_{2002}>\mathrm{R}_{2006}>\mathrm{R}_{0}\right)$. The eutrophication risk index (ERI) ranged between $0.27-2.07 \%$ and decreased with increasing time since restoration, but the relationship was not statistically significant $(\mathrm{P}>0.05)$. A correlation analysis demonstrated that $\mathrm{Fe}_{\mathrm{ox}}, \mathrm{Mg}$, and $\mathrm{Al}_{\mathrm{ox}}$ are the main $\mathrm{P}$ sorption agents in wetland sediments, whereas $\mathrm{TOC}, \mathrm{pH}$, and clay particles have an important effect on P sorption and release. The analysis suggests that we should restore degraded coastal wetlands to help reduce the $\mathrm{P}$ load to offshore waters.
\end{abstract}

\section{Introduction}

Phosphorus (P) is an essential nutrient for ecosystems and a key factor controlling the eutrophication of water bodies (Sundareshwar et al., 2003; Schindler et al., 2008). The rapid social-economic development of coastal environments has increased the input of P from many point and non-point sources to offshore areas, resulting in a multiplefold increase in $\mathrm{P}$ content in offshore waters. For example, the input of labile $P$ to China's offshore waters increased by 2-5 fold from 1970 to 2000 , and it is expected that the amount of $P$ transported by runoff to the coast will continue to increase by $1-3$ fold from 2000 to 2050 (Strokal et al., 2014). Excessive P input has altered P cycling in the offshore ecosystem, and the water body is in a state of severe eutrophication. According to the Bulletin for the Environmental Quality of Coastal Waters in China (2013-2017), the water within all of the important bays in China, including Liaodong Bay, Bohai Bay, the Yangtze River Estuary, and the Pearl River Estuary are heavily polluted, particularly with regards to inorganic nitrogen and labile phosphate. The increase in $\mathrm{P}$ content has triggered frequent occurrences of red and green tides in offshore waters, resulting in the deterioration of water quality, a sharp decline in fishery resources, and an imbalance in the ecosystem. When combined, these changes have seriously affected the sustainable development of the regional economy and its associated natural resources (Smith and Schindler, 2009).

Wetlands are known as the "kidneys" of the Earth, and are a natural purifier for wastewater. Coastal wetlands are located at the intersection of land and sea, and are the last barrier to keep terrestrial pollutants (e.g., P) from entering the ocean. Coastal wetlands have a strong ability to filter external P (Reddy et al., 1999, 2011). Coastal wetlands act as one of the world's most important "sources," "sinks," and "reactors" of $\mathrm{P}$, and therefore play a critical role in the global P cycle (Reddy et al., 2011). Coastal wetlands in the Yellow River Delta (YRD) are one of the youngest and most extensive wetland areas in a warm temperate climate in China. However, in recent years, severe wetland degradation has occurred in the YRD because of reduced freshwater inputs, increased point and non-point source pollution, and the marine erosion of

\footnotetext{
Abbreviations: P, Phosphorus; YRD, Yellow River Delta; EPC0, equilibrium phosphorus concentration; NAP, native adsorbed phosphorus concentration; $\mathrm{Q}_{\text {max }}$

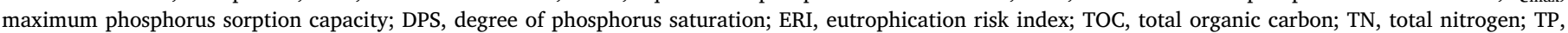

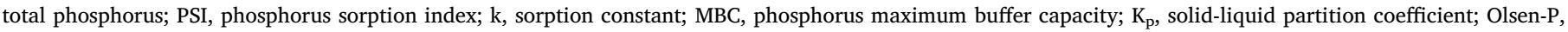
available soil phosphorus

* Corresponding author. 17 Chunhui Road, Laishan District, Yantai, China.

** Corresponding author.

E-mail addresses: gxu@yic.ac.cn (G. Xu), gxhan@yic.ac.cn (G. Han).

${ }^{1}$ The authors contributed equally to the study.
} 
wetland sediments (Wang et al., 2012; Bai et al., 2019a). In response to these threats, flow and sediment regulations were implemented in 2002 at the Xiaolangdi dam to increase water discharge and sediment loads to lower reaches of the Yellow River (Bai et al., 2019b). At the same time, artificial dikes and channels were constructed to deliver Yellow River water to the degraded wetlands. With implementation of these wetland restoration projects, the salinity of the wetlands was reduced, and plant coverage and growth increased, thereby promoting wetlands functioning and wildlife habitats in the Yellow River Delta (Cui et al., 2009; Lu et al., 2018). However, while P is an important nutrient in wetland productivity, little is known about the effects of wetland restoration on the retention capacity and potential loss of $\mathrm{P}$ from sediment within the YRD.

The present study hypothesized that the P storage capacity of wetlands decreases with increasing time since restoration because P sorption sites in the wetland will gradually become saturated. In contrast, the risk of $\mathrm{P}$ loss from the wetland sediments will increase with restoration time. The aims of this study were to (1) characterize P sorption capacity of, and risk of $P$ release from, YRD wetlands restored at different times in the past; (2) identify the main factors controlling $P$ sorption and the risk of P loss from the sediments; and (3) evaluate the policy of wetland restoration based on $\mathrm{P}$ sorption/release.

\section{Materials and methods}

\subsection{Study sites and sample collection}

The study sites $\left(37^{\circ} 26^{\prime}-38^{\circ} 09^{\prime} \mathrm{N}, 118^{\circ} 33^{\prime}-119^{\circ} 18^{\prime} \mathrm{E}\right)$ are located in the Yellow River Delta (YRD) of China (Fig. 1), one of the most active deltas in terms of land-ocean interaction in the world. Large amounts of sediment are carried by the Yellow River and deposited at the river mouth to form the youngest wetland in China. The annual average temperature is $12.1^{\circ} \mathrm{C}$ and the annual average rainfall is $552 \mathrm{~mm}$. The major vegetation in this area includes Phragmites australis, Tamarix chinensis, and Suaeda salsa. The texture of the sediments ranges from loam to silty loam; their organic-matter content was low due to its short formation time and high salinity (Cui et al., 2009). During this study, the effect of freshwater restoration projects on $\mathrm{P}$ storage capacity was investigated in three typical wetlands covered by Phragmites australis.
These three wetlands included a wetland restored in $2002\left(R_{2002}\right)$, a wetland restored in $2006\left(R_{2006}\right)$, and a wetland $\left(R_{0}\right)$ that possessed no restoration projects at the time of data collection.

Within each studied wetland, three sampling sites were selected. At each of these sampling sites, five randomly distributed sediment profile (cores) were collected. The sediment profile was then sectioned at depths of $0-5 \mathrm{~cm}, 5-10 \mathrm{~cm}, 10-20 \mathrm{~cm}$, and $20-40 \mathrm{~cm}$. The sediments from the same depth in the five profiles were combined to get a more representative sample. All of the samples were freeze-dried. Impurities in the samples were subsequently removed, and samples were ground, passed through a $0.149 \mathrm{~mm}$ sieve, and stored in a refrigerator at $4{ }^{\circ} \mathrm{C}$ for future use.

\subsection{Experimental methods}

\subsubsection{Phosphorus sorption experiment}

Duplicated sediments from the three studied wetlands were used for the P sorption experiment. Approximately $1 \mathrm{~g}$ samples were placed into screw-cap centrifuge tubes $(50 \mathrm{~mL})$, along with a $20 \mathrm{~mL}$ phosphate standard solution (as $\mathrm{KH}_{2} \mathrm{PO}_{4}$ ). Concentrations of standards included $0.00,0.50,1.00,2.50,5.00,10.00,15.00,30.00,50.00,75.00,100.00$, $120.00,160.00$, and $240.00 \mathrm{mg} \mathrm{L}^{-1}$. After mixing, the solution was shaken at $25^{\circ} \mathrm{C}$ for $24 \mathrm{~h}$ to reach equilibrium. After shaking, the sample was centrifuged for $10 \mathrm{~min}$ at $4000 \mathrm{r} \cdot \mathrm{min}^{-1}$ (Nair and Reddy, 2013). The supernatant was filtered through a $0.45 \mu \mathrm{m}$ membrane and the $\mathrm{P}$ content was measured by a continuous flow technique. The sorbed $\mathrm{P}$ was calculated by the difference between the added amount of $\mathrm{P}$ and the measured amount of $\mathrm{P}$ in the equilibrium solution.

The sorption data were fitted using a modified Langmuir model, and the maximum $\mathrm{P}$ sorption capacity $\left(\mathrm{Q}_{\max }\right)$ and sorption constant $(\mathrm{k})$ of the sediment were obtained from the model. The modified Langmuir sorption isotherm parameters are expressed in equations (1)-(5) (Zhou et al., 2005).

$Q_{e}=\frac{Q_{\max } \times k \times C_{e}}{1+k \times C_{e}}-N A P$

$\mathrm{MBC}=Q_{\max } \times k$

$\mathrm{NAP}=\frac{Q_{\max } \times k \times C_{0}}{1+k \times C_{0}}+C_{0} \frac{V}{W}$
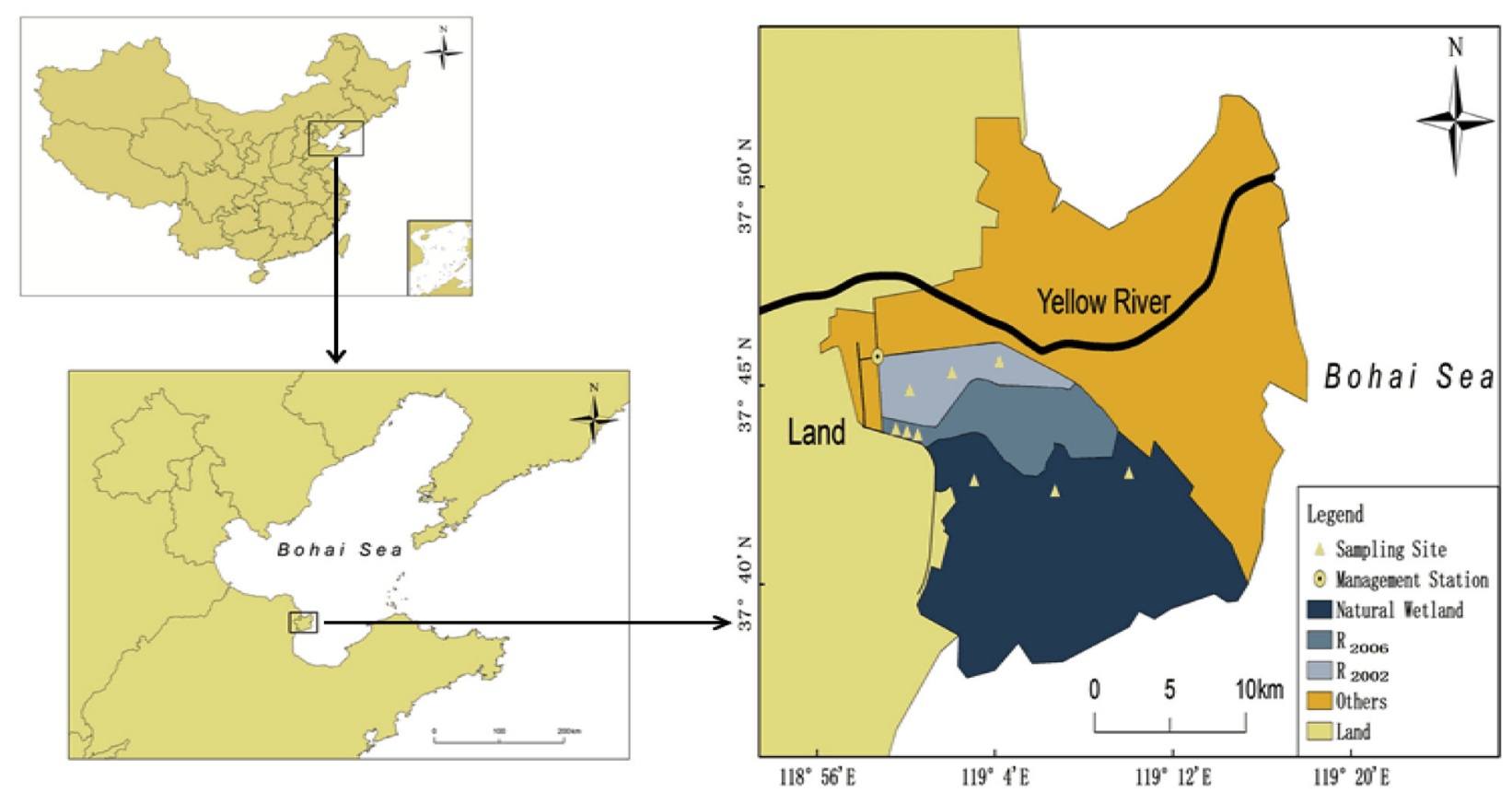

Fig. 1. Maps showing (A) the location of Bohai Sea in China; (B) the location of the study area in the Bohai Sea, and (C) the location of the sampled wetlands. 


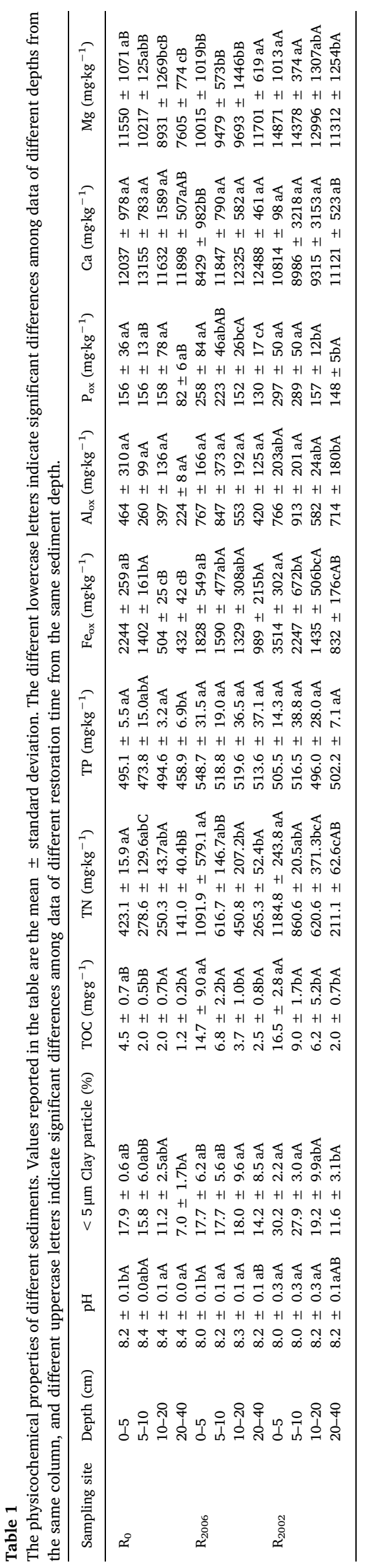

$\mathrm{NAP}=\frac{Q_{\max } \times k \times E P C_{0}}{1+k \times E P C_{0}}$

$K_{p}=\frac{N A P}{E P C_{0}}$

where $\mathrm{Q}_{\mathrm{e}}\left(\mathrm{mg} \mathrm{kg}^{-1}\right)$ and $\mathrm{Q}_{\max }\left(\mathrm{mg} \mathrm{kg}^{-1}\right)$ are the equilibrium amount and the maximum amount of $\mathrm{P}$ sorbed onto sediment, respectively; $\mathrm{C}_{0}$ $\left(\mathrm{mgL}^{-1}\right)$ is the equilibrium $\mathrm{P}$ concentration when the initial phosphorus in the solution was $0 \mathrm{mg} \mathrm{L}^{-1} ; \mathrm{C}_{\mathrm{e}}\left(\mathrm{mg} \mathrm{L}^{-1}\right)$ is the equilibrium $\mathrm{P}$ concentration; $\mathrm{k}\left(\mathrm{L} \mathrm{mg}^{-1}\right)$ is the Langmuir equilibrium constant; $\mathrm{MBC}$ (L $\left.\mathrm{kg}^{-1}\right)$ is the $\mathrm{P}$ maximum buffer capacity; NAP $\left(\mathrm{mg} \mathrm{kg}^{-1}\right)$ is the native adsorbed P; EPC0 ( $\left.\mathrm{mg} \mathrm{L}^{-1}\right)$ is the zero equilibrium P concentration; and $\mathrm{K}_{\mathrm{P}}$ is the distribution coefficient for a solid and liquid.

\subsubsection{Assessing the risk of $P$ release}

The P sorption index (PSI) and degree of P saturation (DPS) are frequently used to characterize the $\mathrm{P}$ sorption capacity and potential risks of P release from sediments (Bache and Williams, 1971; Sekhon et al., 2014). The available soil P (Olsen-P) concentration in the sediments was extracted using a $0.5 \mathrm{~mol} \mathrm{~L}^{-1} \mathrm{NaHCO}_{3}$ solution and subsequently determined colorimetrically. The DPS of the sediment was obtained according to the following equation (Jin et al., 2006):

DPS $=\frac{\text { Olsen }-P}{\text { Olsen }-P+Q_{\max }} \times 100 \%$

\subsection{The PSI was calculated as}

PSI $=\frac{X}{\lg C}$

where PSI $\left(\mathrm{L} \mathrm{kg}^{-1}\right)$ denotes $\mathrm{P}$ sorption index, $\mathrm{X}\left(\mathrm{mg} \mathrm{kg}^{-1}\right)$ is the amount of $\mathrm{P}$ sorbed and $\mathrm{C}\left(\mathrm{mg} \mathrm{L}^{-1}\right)$ is the equilibrium $\mathrm{P}$ concentration of filtrate after equilibration was reached between a $1 \mathrm{~g}$ sediment sample and $20 \mathrm{~mL}$ of a $75 \mathrm{mg} \mathrm{P} \mathrm{L}^{-1}$ solution in an end-over shaker for $24 \mathrm{~h}$ (Gao et al., 2018).

Huang et al. (2004) proposed a P eutrophication risk index (ERI), which is calculated on the basis of sediment PSI and DPS. ERI was then used to evaluate the risk posed by $\mathrm{P}$ in surface sediments. ERI was calculated using the method proposed by Huang et al. (2004), where

$\mathrm{ERI}=\frac{D P S}{P S I} \times 100 \%$

\subsubsection{Sediment chemical analysis}

The $\mathrm{pH}$ of the sediment was measured by a $\mathrm{pH}$ meter (soil to water ratio: 1:2.5); total $\mathrm{P}$ (TP) was determined using the molybdenum blue colorimetric method after digestion using a mixture of concentrated sulfuric acid-perchloric acid (Murphy and Riley, 1962). Total organic carbon (TOC) and total nitrogen (TN) were determined using an elemental analyzer (TOC-VCPH, Shimadu). Amorphous iron $\left(\mathrm{Fe}_{\mathrm{o}}\right)$ and aluminum $\left(\mathrm{Al}_{\mathrm{o}}\right)$ oxides were extracted using ammonium oxalate, and their concentrations were determined by inductively coupled plasma atomic emission spectroscopy (ICP-AES) (Bai et al., 2017). Calcium (Ca) and magnesium $(\mathrm{Mg})$ were extracted using a $1 \mathrm{~mol} \mathrm{~L}^{-1}$ hydrochloric acid solution; their concentrations were then determined using an atomic absorption spectrophotometer (TAS-990) (Pant and Reddy, 2001). The particle size distribution of the sediments was determined using a laser diffraction particle size analyzer (Mastersizer, 2000; Malvern, England). During the determinations of TOC, TN, and TP concentrations, a standard sample (GBW07427) was used for quality control. The measured error of the standard samples was less than $5 \%$.

\subsection{Statistical analysis}

All data are reported as the mean and standard deviation of three 
replicates. One-way ANOVA was carried out using the SPSS computer package (SPSS Inc. 1999; Chicago, USA), and significant differences between means were determined using an LSD test. Differences were considered statistically significant at the $\mathrm{P}<0.05$ level. A two-tailed Pearson correlation analysis was used to determine the correlations between $\mathrm{P}$ sorption parameters and physicochemical parameters in the sediment. The SigmaPlot 10.0 software package was used to fit isotherms to the phosphorus sorption data using modified Langmuir models.

\section{Results}

\subsection{Physicochemical properties of Yellow River Delta sediments}

The physicochemical properties of sediments collected from the three sampled wetlands within the YRD are shown in Table 1 . The $\mathrm{pH}$ of the wetland sediments ranged from 7.6 to 8.5 and was slightly alkaline. Sediment $\mathrm{pH}$ did not change considerably with time since restoration and decreased with increasing depth. The TOC and TN contents in the sediments ranged between $1.1-22.8 \mathrm{mg} \mathrm{g}^{-1}$ and $112.4-1643.7 \mathrm{mg} \mathrm{kg}^{-1}$, respectively. Their concentrations gradually increased with increasing time since restoration $\left(R_{2002}>R_{2006}>R_{0}\right)$, but decreased with increasing sediment depth. The clay content of the wetland sediments ranged from $5.8 \%$ to $32.7 \%$. The amount of clay at sites $\mathrm{R}_{2002}$ and $\mathrm{R}_{2006}$ were higher than that in $\mathrm{R}_{0}$; the clay content at all sites decreased with increasing depth. The TP content in the sediment ranged from 454.0 to $587.8 \mathrm{mg} \mathrm{kg}^{-1}$. Significant changes in TP content were only observed between the surface $(0-5 \mathrm{~cm})$ and bottom layers $(20-40 \mathrm{~cm})$ of $\mathrm{R}_{0}$. The $\mathrm{Fe}_{\mathrm{ox}}$ and $\mathrm{Al}_{\mathrm{ox}}$ contents varied between $403-3845 \mathrm{mg} \mathrm{kg}^{-1}$ and $190-1137 \mathrm{mg} \mathrm{kg}^{-1}$, respectively. An increase in the $\mathrm{Fe}_{\mathrm{ox}}$ concentration occurred in the surface layer $(0-5 \mathrm{~cm})$ at $\mathrm{R}_{2002}$ in comparison to $\mathrm{R}_{2006}$ or $\mathrm{R}_{0}$. Otherwise, $\mathrm{Fe}_{\mathrm{ox}}$ contents did not vary significantly with restoration time. The $\mathrm{Fe}_{\mathrm{ox}}$ content generally decreased with increasing sediment depth in each wetland, while $\mathrm{Al}_{\mathrm{ox}}$ concentrations did not change significantly with depth. The Ca content (8429-13155 $\mathrm{mg} \mathrm{kg}^{-1}$ ) did not change significantly with the restoration time or with depth in the wetland sediments. The Mg content (7605-12996 $\mathrm{mg} \mathrm{kg}^{-1}$ ) in the sediment ranked in the order of $R_{2002}>R_{2006} \approx R_{0}$. The Mg content of the surface sediments $(0-5 \mathrm{~cm}$ and 5-10 cm) at $R_{2002}$ and $R_{0}$ were significantly higher than that of the bottom layers $(20-40 \mathrm{~cm})$ at the two plots.

\subsection{Phosphorus sorption isotherm characteristics of wetland sediments}

As is shown by the $\mathrm{P}$ sorption isotherm parameters $\left(\mathrm{R}^{2}>0.94\right)$ (Fig. 2, Table 2), the modified Langmuir model accurately described the sorption behavior of $\mathrm{P}$ in sediments of the YRD. The maximum $\mathrm{P}$ sorption $\left(Q_{\max }\right)$ values ranged between $201.8-1168.6 \mathrm{mg} \mathrm{kg}^{-1}$ with an average of $576.2 \mathrm{mg} \mathrm{kg}^{-1}$. $Q_{\max }$ values followed the order of $\mathrm{R}_{2002}>\mathrm{R}_{2006}>\mathrm{R}_{0}$. The $\mathrm{Q}_{\max }$ values gradually decreased with increasing sediment depth. The $Q_{\max }$ of the surface layer $(0-5 \mathrm{~cm})$ was significantly higher $(\mathrm{P}<0.05)$ in comparison to those of the lower layers $(10-20 \mathrm{~cm}$ and $20-40 \mathrm{~cm})$. The $\mathrm{k}$ values varied between 0.040 and $0.290 \mathrm{~L} \mathrm{mg}^{-1}$, whereas the $\mathrm{P}$ maximum buffer capacity (MBC) ranged between 11.5 and $163.6 \mathrm{~L} \mathrm{~kg}^{-1}$. The $\mathrm{k}$ and $\mathrm{MBC}$ values did not statistically change with time since restoration or with sediment depth.

The natural adsorbed $\mathrm{P}$ (NAP) in the sediments ranged between $0.009-0.375 \mathrm{mg} \mathrm{kg}^{-1}$, whereas the $\mathrm{EPC}_{0}$ ranged between $0.0006-0.0029 \mathrm{mg} \mathrm{L}^{-1}$. Changes in NAP and $\mathrm{EPC}_{0}$ values with restoration time were insignificant $(\mathrm{P}>0.05)$. However, the NAP and $\mathrm{EPC}_{0}$ values of the surface sediments $(0-5 \mathrm{~cm}$ or $0-10 \mathrm{~cm})$ were significantly higher $(\mathrm{P}<0.05)$ than those of the lower $(10-20 \mathrm{~cm})$ and bottom sediments $(20-40 \mathrm{~cm})$.

\subsection{Assessment of phosphorus sorption/release risk}

The PSI of YRD sediments varied from $8.28-50.33 \mathrm{mgL} /(100 \mathrm{~g}$ $\mu \mathrm{mol})$ with an average of $26.65 \mathrm{mgL} /(100 \mathrm{~g} \mu \mathrm{mol})$ (Fig. 3). Overall, the PSI of the surface sediments $(0-5 \mathrm{~cm}$ and $5-10 \mathrm{~cm})$ was larger than those of the lower $(10-20 \mathrm{~cm})$ and bottom sediments $(20-40 \mathrm{~cm})$. The PSI values varied in the order of $R_{2002}>R_{2006}>R_{0}$, which is consistent with the change in $\mathrm{Q}_{\max }$ between sites. The DPS of the wetland sediments ranged from $0.27 \%$ to $2.07 \%$ and averaged $0.80 \%$. DPS did not change significantly with time since restoration or depth (Fig. 3). The ERI value of the wetland sediments from YRD varied from $0.68 \%$ to $13.89 \%$ (Fig. 3). As the time since restoration increased, the ERI values generally followed the order of $\mathrm{R}_{2002}<\mathrm{R}_{2006}<\mathrm{R}_{0}$ although differences among the three plots were not statistically significant $(\mathrm{P}>0.05)$.

\subsection{Correlation analysis between P sorption/release behavior and sediment characteristics}

As shown in Table 3, there was a significant negative correlation between $\mathrm{Q}_{\max }$ and $\mathrm{pH}(\mathrm{P}<0.01)$, and a significant positive correlation in the concentrations of $\mathrm{Fe}_{\mathrm{ox}}, \mathrm{Al}_{\mathrm{ox}}, \mathrm{TOC}, \mathrm{TN}$, and $\mathrm{Mg}$, as well as the
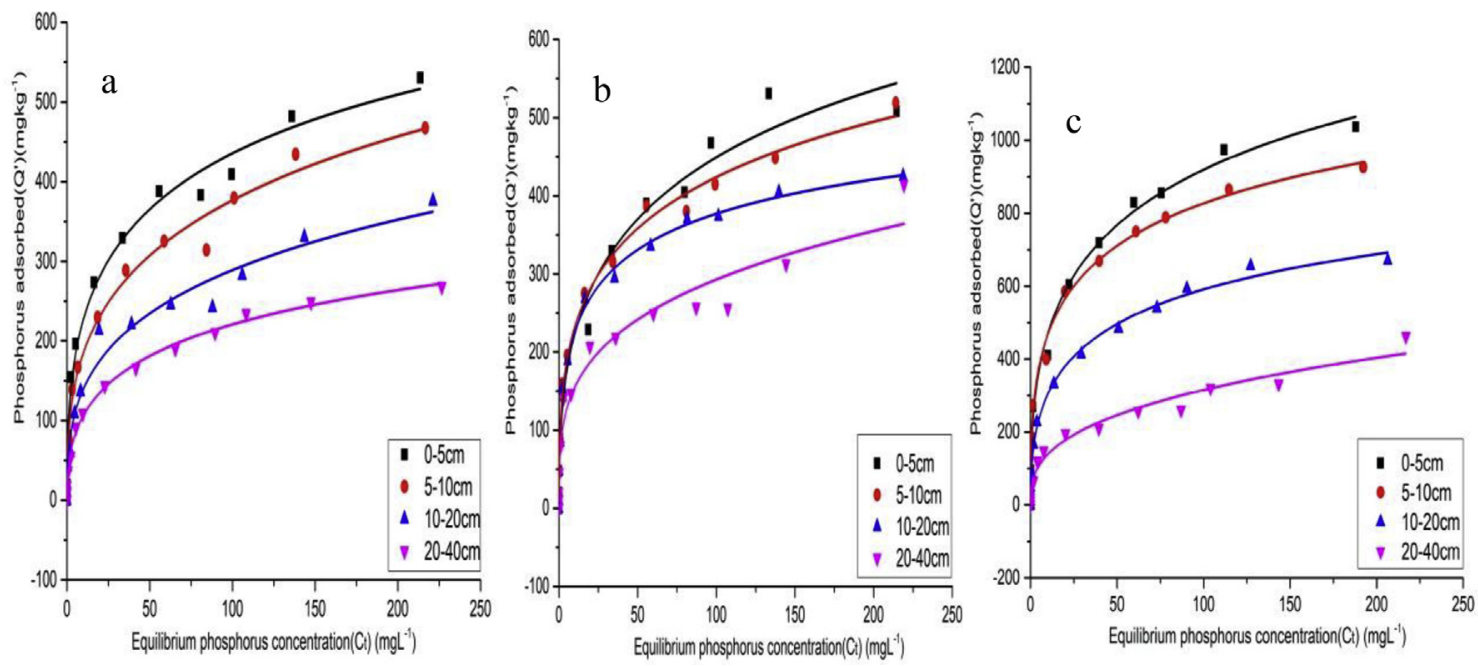

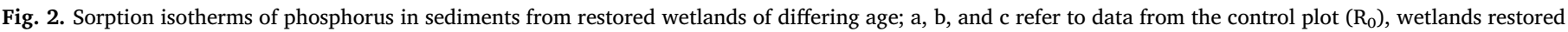
since $2006\left(R_{2006}\right)$, and wetlands restored since $2002\left(R_{2002}\right)$, respectively. 
Table 2

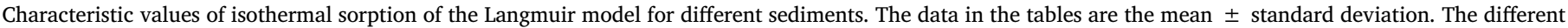

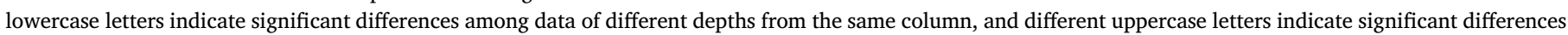
among data of different restoration times from the same sediment depth.

\begin{tabular}{|c|c|c|c|c|c|c|c|}
\hline & $\mathrm{Q}_{\max }\left(\mathrm{mg} \cdot \mathrm{kg}^{-1}\right)$ & $\mathrm{k}\left(\mathrm{L} \mathrm{mg}^{-1}\right)$ & $\operatorname{MBC}\left(\mathrm{L} \mathrm{kg}^{-1}\right)$ & $\mathrm{R}^{2}$ & NAP (mg.kg $\left.{ }^{-1}\right)$ & $\mathrm{EPC}_{0}\left(\mathrm{mg} \cdot \mathrm{L}^{-1}\right)$ & $\mathrm{Kp}\left(\mathrm{L} \mathrm{kg}^{-1}\right)$ \\
\hline $\mathrm{R}_{0}(0-5)$ & $494.1 \pm 8.6 \mathrm{aB}$ & $0.113 \pm 0.054 \mathrm{aA}$ & $55.8 \pm 27.9 \mathrm{aA}$ & 0.96 & $0.114 \pm 0.044 \mathrm{aA}$ & $0.0021 \pm 0.0003 \mathrm{aA}$ & $55.8 \pm 27.9 \mathrm{aA}$ \\
\hline $\mathrm{R}_{0}(5-10)$ & $455.7 \pm 189.3 \mathrm{aB}$ & $0.086 \pm 0.048 \mathrm{aA}$ & $34.6 \pm 5.6 \mathrm{aB}$ & 0.96 & $0.041 \pm 0.007 \mathrm{bB}$ & $0.0012 \pm 0.0000 \mathrm{bA}$ & $34.6 \pm 5.6 \mathrm{aB}$ \\
\hline $\mathrm{R}_{0}(10-20)$ & $333.4 \pm 121.4 \mathrm{aA}$ & $0.086 \pm 0.028 \mathrm{aA}$ & $26.9 \pm 1.2 \mathrm{aA}$ & 0.94 & $0.021 \pm 0.004 \mathrm{bA}$ & $0.0007 \pm 0.0001 \mathrm{bA}$ & $26.9 \pm 1.2 \mathrm{aA}$ \\
\hline $\mathrm{R}_{0}(20-40)$ & $259.4 \pm 81.5 \mathrm{aA}$ & $0.071 \pm 0.012 \mathrm{aA}$ & $17.8 \pm 2.6 \mathrm{aA}$ & 0.96 & $0.015 \pm 0.005 \mathrm{bA}$ & $0.0008 \pm 0.0001 \mathrm{bA}$ & $17.8 \pm 2.6 \mathrm{aA}$ \\
\hline $\mathrm{R}_{2006}(0-5)$ & $589.2 \pm 220.5 \mathrm{aB}$ & $0.141 \pm 0.047 \mathrm{aA}$ & $88.1 \pm 55.6 \mathrm{aA}$ & 0.95 & $0.230 \pm 0.134 \mathrm{aA}$ & $0.0027 \pm 0.0002 \mathrm{aA}$ & $88.1 \pm 55.6 \mathrm{aA}$ \\
\hline $\mathrm{R}_{2006}(5-10)$ & $567.4 \pm 216.5 \mathrm{aB}$ & $0.162 \pm 0.044 \mathrm{aA}$ & $86.1 \pm 19.7 \mathrm{aA}$ & 0.94 & $0.138 \pm 0.061 \mathrm{abA}$ & $0.0016 \pm 0.0005 \mathrm{bA}$ & $86.1 \pm 19.7 \mathrm{aA}$ \\
\hline $\mathrm{R}_{2006}(10-20)$ & $548.5 \pm 314.5 \mathrm{aA}$ & $0.210 \pm 0.089 \mathrm{aA}$ & $98.6 \pm 24.3 \mathrm{aA}$ & 0.96 & $0.105 \pm 0.049 \mathrm{bA}$ & $0.0010 \pm 0.0003 \mathrm{cA}$ & $98.6 \pm 24.3 \mathrm{aA}$ \\
\hline $\mathrm{R}_{2006}(20-40)$ & $384.8 \pm 93.3 \mathrm{aA}$ & $0.146 \pm 0.097 \mathrm{aA}$ & $49.4 \pm 26.6 \mathrm{aA}$ & 0.95 & $0.038 \pm 0.020 \mathrm{bA}$ & $0.0008 \pm 0.0001 \mathrm{cA}$ & $49.4 \pm 26.6 \mathrm{aA}$ \\
\hline $\mathrm{R}_{2002}(0-5)$ & $998.0 \pm 198.1 \mathrm{aA}$ & $0.085 \pm 0.050 \mathrm{aA}$ & $78.0 \pm 30.5 \mathrm{aA}$ & 0.96 & $0.173 \pm 0.080 \mathrm{aA}$ & $0.0022 \pm 0.0004 \mathrm{aA}$ & $78.0 \pm 30.5 \mathrm{aA}$ \\
\hline $\mathrm{R}_{2002}(5-10)$ & $943.0 \pm 153.2 \mathrm{aA}$ & $0.110 \pm 0.021 \mathrm{aA}$ & $102.1 \pm 10.0 \mathrm{aA}$ & 0.95 & $0.157 \pm 0.010 \mathrm{aA}$ & $0.0015 \pm 0.0001 \mathrm{bA}$ & $102.1 \pm 10.0 \mathrm{aA}$ \\
\hline $\mathrm{R}_{2002}(10-20)$ & $669.7 \pm 237.0 \mathrm{abA}$ & $0.151 \pm 0.065 \mathrm{aA}$ & $103.7 \pm 58.9 \mathrm{aA}$ & 0.95 & $0.107 \pm 0.055 \mathrm{abA}$ & $0.0011 \pm 0.0003 \mathrm{bcA}$ & $103.7 \pm 58.9 \mathrm{aA}$ \\
\hline $\mathrm{R}_{2002}(20-40)$ & $444.5 \pm 188.5 \mathrm{bA}$ & $0.084 \pm 0.039 \mathrm{aA}$ & $33.5 \pm 1.5 \mathrm{aA}$ & 0.94 & $0.031 \pm 0.005 \mathrm{bA}$ & $0.0009 \pm 0.0002 \mathrm{cA}$ & $33.5 \pm 1.5 \mathrm{aA}$ \\
\hline
\end{tabular}

percentage of clay particles in the sample $(\mathrm{P}<0.01)$. ERI exhibited the opposite pattern. NAP, $\mathrm{EPC}_{0}$ and $\mathrm{K}_{\mathrm{p}}$ exhibited a significant negative correlation with $\mathrm{pH}(\mathrm{P}<0.01)$, and a significant positive correlation in the contents of $\mathrm{Fe}_{\mathrm{ox}}, \mathrm{Al}_{\mathrm{ox}}, \mathrm{TOC}, \mathrm{TN}, \mathrm{Mg}$ and clay particles $(\mathrm{P}<0.01)$.

\section{Discussion}

\subsection{Factors affecting phosphorus sorption and release}

Phosphorus sorption by wetland sediments is the predominant mechanism through which P is removed from water (Reddy et al., 1999). Previous studies have shown that $\mathrm{P}$ sorption by sediments is controlled by several parameters, including the type and content of clay particles, organic matter content, $\mathrm{Fe}$ and $\mathrm{Al}$ oxide concentrations, $\mathrm{Ca}$ and $\mathrm{Mg}$ concentrations, and sediment $\mathrm{pH}$ (Antoniadis et al., 2016). Generally, for sediments with a $\mathrm{pH}<6.5$, amorphous $\mathrm{Fe}$ and $\mathrm{Al}$ oxides determine P sorption; however, for sediments with a $\mathrm{pH}>7.5$, Ca and $\mathrm{Mg}$ species tend to dictate $\mathrm{P}$ sorption (DeLaune and Reddy, 2008). The $\mathrm{pH}$ of wetland sediments in the YRD was slightly alkaline $(\mathrm{pH}>7.5)$ (Table 1 ). The correlation analysis suggested that $\mathrm{Fe}_{\mathrm{ox}}, \mathrm{Mg}$, and $\mathrm{Al}_{\mathrm{ox}}$ are the main regulators of $\mathrm{P}$ sorption, while the sorption capacity of $\mathrm{P}$ by $\mathrm{Ca}$ species was not pronounced. This is consistent with previous studies in which the Ca binding capacity for $\mathrm{P}$ was smaller than that for $\mathrm{Fe} / \mathrm{Al}$ oxides in slightly alkaline sediments $(\mathrm{pH}<9)$ (Reddy et al., 1999). The lower degree to which $\mathrm{P}$ was sorbed to Ca was likely due to the longer time needed for Ca to bind with P (Barrow, 1978; Bai et al., 2017). Both the calcium sorption of $P$ and the precipitation of $P$ increase with increasing $\mathrm{pH}$ in alkaline sediments (Ann et al., 1999). If the binding of $\mathrm{P}$ to $\mathrm{Ca}$ dominates $\mathrm{P}$ sorption, a positive correlation between $\mathrm{Q}_{\max }$ and $\mathrm{pH}$ is expected. However, the significant negative correlation between $\mathrm{Q}_{\max }$ and $\mathrm{pH}(\mathrm{P}<0.01)$ observed herein indicated that the sorption of $\mathrm{P}$ to $\mathrm{Ca}$ in the YRD was negligible. There are studies that suggest that $\mathrm{Ca}$ species regulate $\mathrm{P}$ sorption in alkaline soil (Bertrand et al., 2003; Ige et al., 2005a,b). Ige et al. (2005a,b), for example, suggested that $\mathrm{Ca}$ and $\mathrm{Mg}$ concentrations, extracted using the Mehlich 3 solution, could be used to characterize the $\mathrm{P}$ sorption capacity of calcareous soils. In addition, more than $78 \%$ of the $\mathrm{P}$ in the wetland sediments of the YRD is Ca phosphate (Xu et al., 2012). Therefore, the long-term $\mathrm{P}$ retention by $\mathrm{Ca}$ species in the YRD is unclear and requires further study.

Organic matter is also an important factor affecting P sorption, but the sorption mechanism is relatively complicated. Organic matter can absorb P through metal bridging (Delaune and Reddy, 2008). On the other hand, organic matter including low-molecular-weight carboxylic acids can reduce $\mathrm{P}$ sorption capacity by competing with $\mathrm{P}$ for binding sites. Organic matter may also inhibit the crystallization of $\mathrm{Fe}$ and $\mathrm{Al}$ oxides by complexation, decreasing the total sorption capacity for $\mathrm{P}$ (Guppy et al., 2005). The wetland restoration projects in the YRD significantly increased organic matter content thereby increasing P sorption through metal bridging (Cui et al., 2009). The P-fixation capacity of sediments is also related to clay particle content. A higher content of clay particles leads to a larger specific surface area of the sediment, increasing the P-fixation capacity (Stumm, 1992).

The DPS of the sediments is an indicator of the percentage of $\mathrm{P}$ adsorbed by sediment to the total P sorption capacity. It can therefore be used to evaluate the P sorption capacity of sediments and assess the risk of losing $\mathrm{P}$ by leaching and runoff (Sekhon et al., 2014). It is
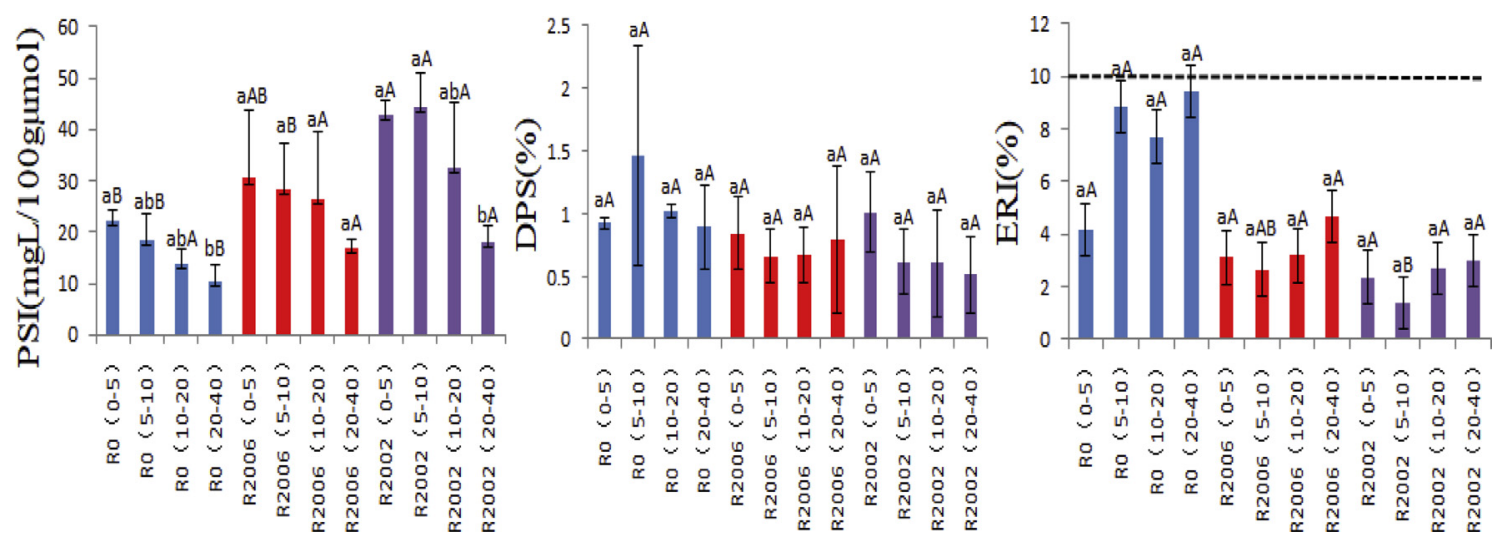

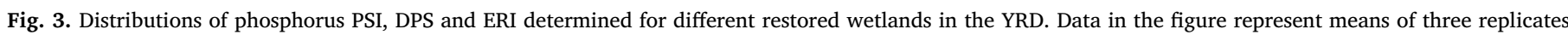

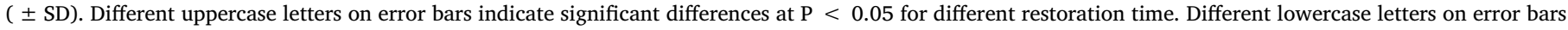
indicate significant differences at $\mathrm{P}<0.05$ for different sediment depth. The dashed line indicates low risk (ERI $<10$ ) values of $\mathrm{P}$ from sediments. 
Table 3

Correlation analysis between phosphorus sorption/release and physicochemical parameters in sediment samples from the YRD.

\begin{tabular}{|c|c|c|c|c|c|c|c|c|}
\hline & $\mathrm{pH}$ & Feox & Alox & TOC & $\mathrm{TP}$ & Clay particles & $\mathrm{HCl}-\mathrm{Ca}$ & $\mathrm{HCl}-\mathrm{Mg}$ \\
\hline Qmax & $-440^{\mathrm{b}}$ & $0.805^{\mathrm{b}}$ & $0.488^{\mathrm{b}}$ & $0.663^{\mathrm{b}}$ & 0.174 & $0.871^{\mathrm{b}}$ & -0.280 & $0.702^{\mathrm{b}}$ \\
\hline DPS & 0.158 & 0.029 & -0.208 & -0.013 & -0.039 & -0.102 & 0.164 & -0.187 \\
\hline ERI & $0.458^{\mathrm{b}}$ & $-0.466^{\mathrm{b}}$ & $-0.523^{b}$ & $-0.447^{\mathrm{b}}$ & -0.289 & $-0.523^{b}$ & 0.258 & $-0.527^{\mathrm{b}}$ \\
\hline $\mathrm{K}$ & -0.122 & -0.074 & 0.145 & 0.036 & 0.126 & 0.012 & -0.080 & -0.078 \\
\hline NAP & $-0.640^{\mathrm{b}}$ & $0.622^{\mathrm{b}}$ & $0.571^{\mathrm{b}}$ & $0.876^{\mathrm{b}}$ & $0.394^{\mathrm{a}}$ & $0.549^{b}$ & $-0.394^{\mathrm{a}}$ & $0.344^{\mathrm{a}}$ \\
\hline $\mathrm{EPC}_{0}$ & $-0.564^{b}$ & $0.601^{\mathrm{b}}$ & $0.430^{\mathrm{a}}$ & $0.702^{\mathrm{b}}$ & $0.386^{\mathrm{a}}$ & 0.327 & $-0.369^{\mathrm{a}}$ & 0.158 \\
\hline Kp & $-0.514^{\mathrm{a}}$ & $0.485^{b}$ & $0.518^{\mathrm{b}}$ & $0.584^{\mathrm{b}}$ & 0.194 & $0.631^{\mathrm{b}}$ & $-0.360^{\mathrm{a}}$ & $0.464^{\mathrm{b}}$ \\
\hline MBC & $-0.514^{\mathrm{a}}$ & $0.485^{b}$ & $0.518^{\mathrm{b}}$ & $0.584^{\mathrm{b}}$ & 0.194 & $0.631^{\mathrm{b}}$ & $-0.360^{\mathrm{a}}$ & $0.464^{\mathrm{b}}$ \\
\hline
\end{tabular}

a Significantly correlated at the 0.05 level.

b Significantly correlated at the 0.01 level (two-tailed test).

generally believed that low DPS values indicate that P sorption sites in the sediment are not saturated, and the sediment will have a relatively high P sorption capacity (Nair, 2014). The DPS of the sediments in the YRD ranges between $0.27-2.07 \%$, which is lower than that in the Okeechobee wetland of Florida, USA (5-18\%) (Dunne et al., 2006), and the Minjiang River Estuary in China (7.3\%) (Gao et al., 2018). It is also considerably lower than those of inland reservoirs, such as the Beijing urban reservoirs in China (7.97-50.5\%) (Lu et al., 2011) and the Taihu reservoirs in China (3.8-15.3\%) (Jin et al., 2006). The relatively low DPS values indicate that the wetlands of the YRD have a greater potential to adsorb or remove $\mathrm{P}$ from water.

The $\mathrm{EPC}_{0}$ of sediments is an important indicator for determining the $\mathrm{P}$ adsorbed by, or released from, sediments. When the concentration of soluble $\mathrm{P}$ in the overlying water is $>\mathrm{EPC}_{0}$, the sediment will adsorb $\mathrm{P}$ from the water body, and the sediment will act as a P sink. Otherwise, $\mathrm{P}$ will likely be released to the water body, and the sediment will serve as a $\mathrm{P}$ source. The $\mathrm{EPC}_{0}$ in the present study ranged from 0.0006 to $0.0029 \mathrm{mg} \mathrm{L}^{-1}$, which was lower than the $\mathrm{P}$ concentration of the overlying water $\left(0.016-0.126 \mathrm{mg} \mathrm{L}^{-1}\right)$. Therefore, the wetland sediments within the YRD are likely to serve as a P sink and have a high potential to remove $P$ from surface water. The relatively lower DPS and $\mathrm{EPC}_{0}$ values maybe related to the relatively low P loads (see details in section 4.3) and to limited soil development due to young age of the sediments within the YRD (Bai et al., 2019a,b).

ERI can be used to subdivide the risk of eutrophication induced by $P$ into four categories: very high risk (ERI $>25$ ), high risk $(20<$ ERI < 25), moderate risk $(10<$ ERI < 20) and low risk (ERI < 10) (Huang et al., 2004). The ERI of the YRD varied between $0.68 \%$ and $13.89 \%$. These values are similar to those of the wetlands in the Minjiang River Estuary in China (9.6-10.6\%) (Gao et al., 2018), but are much lower than those of inland wetlands, such as the Beijing urban reservoirs in China (17.2-247.2\%) (Lu et al., 2011) and the Taihu reservoirs in China (10-55\%) (Jin et al., 2006). These ERI values indicate that the risk of P release from sediments in the YRD is generally low, which is consistent with the fact that the YRD has not experienced large-scale eutrophication (Bai et al., 2012).

\subsection{Comparison of wetlands in the Yellow River Delta with other wetlands}

The YRD wetlands exhibited TP, $\mathrm{Q}_{\max }$, and $\mathrm{K}_{\mathrm{p}}$ values, and thus a $\mathrm{P}$ sorption potential, similar to other coastal wetlands (Table 4). However, $\mathrm{k}$, NAP, and $\mathrm{EPC}_{0}$ values were significantly lower than in other coastal wetlands. The parameter $\mathrm{k}$ is the half-saturation concentration and contrasts with the surface binding energy. The significantly lower $\mathrm{k}$ suggests that the wetland sediments in the YRD had a higher affinity for P than the sediments in other coastal wetlands (Zhou et al., 2005). The higher affinity for $\mathrm{P}$ maybe explained by the young age of the sediments within the YRD because the binding energy constant is controlled by strong sorption sites during the early stage of P sorption (Lin et al., 2009). NAP, which is also an indicator of sediment exchangeable $P$, tends to be in equilibrium with $\mathrm{P}$ in the water body and is therefore a measure of the degree of $\mathrm{P}$ water pollution (Wang et al., 2005; Jin et al., 2006). The NAP value of the YRD wetlands $\left(0.009-0.375 \mathrm{mg} \mathrm{kg}^{-1}\right.$ ) was substantially lower than that of the Hangzhou Bay tidal flats (1.853-4.777 $\mathrm{mg} \mathrm{kg}^{-1}$ ) (X. Shao et al., 2014) and wetlands within the Yangtze River Estuary (1.23-36.05 $\mathrm{mg} \mathrm{kg}^{-1}$ ) (Liu et al., 2002), indicating that only a small amount of $\mathrm{P}$ is being desorbed from sediments in YRD wetland. The $\mathrm{EPC}_{0}$ of the YRD wetlands was 1-2 orders of magnitude lower than those of other coastal wetlands, suggesting that the YRD wetlands possess a larger potential to remove $P$ from the water.

Compared to coastal wetlands, more than $66 \%$ of inland reservoirs exhibit eutrophic conditions and $22 \%$ of all water bodies are hypereutrophic in China (Zhang et al., 2008). The rank order of P dynamics in sediments was consistent with the trophic status of inland reservoirs. As a result, a comparison between different polluted inland and coastal wetlands may provide insights into $\mathrm{P}$ storage and release from coastal wetlands. Coastal wetlands exhibited similar $\mathrm{TP}, \mathrm{Q}_{\max }, \mathrm{k}$, and $\mathrm{EPC}_{0}$ values to inland wetlands (Table 4). However, the NAP values of coastal wetlands were generally 1-2 orders of magnitude lower than the inland reservoirs (Table 4). The NAP value is positively correlated with the degree of eutrophication (Wang et al., 2005; Jin et al., 2006). For example, the sediment NAP values in eutrophic and moderately eutrophic areas of the Taihu were $44-380 \mathrm{mg} \mathrm{kg}^{-1}$ and $12-15 \mathrm{mg} \mathrm{kg}^{-1}$, respectively (Zhou et al., 2005). The $K_{p}$ value reflects the affinity of $P$ for sediments (Zhou et al., 2005). The $K_{p}$ value of the coastal wetlands tended to be lower than that of the inland reservoirs (Table 4). That is, $\mathrm{P}$ in coastal wetlands is more easily stored in the water than in sediment (Wang and Pant, 2010).

The YRD was formed slightly more than 100 year ago since the watercourse of the Yellow River changed in 1855. Compared to the long-term formation of other coastal wetlands (such as Yangtze River delta) (Saito et al., 2001), the YRD is the youngest coastal wetland in China, and is characterized by low levels of soil development (Yu et al., 2016; Bai et al., 2017). Progressive soil development has proved to increase P sorption capacity due to organic matter accumulation (Zou et al., 2011). In other words, the restored YRD sediments show great potential for $\mathrm{P}$ sorption capacity while low risk of $\mathrm{P}$ release to the adjacent ocean.

\subsection{Significance of wetland restoration to the phosphorus cycle}

Wetland restoration in the YRD has been conducted by introducing water into wetlands, which resulted in an increase in plant growth and coverage, an increase in biodiversity (e.g., benthic organisms and birds) and improvements in ecosystem health (Cui et al., 2009). This study showed that with increasing restoration time, sediment $\mathrm{Q}_{\max }$ increased, indicating that wetland restoration can increase the $\mathrm{P}$ sorption capacity of wetland sediments (Fig. 4). Values of MBC, NAP, and $\mathrm{EPC}_{0}$ did not significantly change with time since restoration, nor was there a significant increase in wetland DPS and ERI (Fig. 4). These results demonstrate that wetland restoration did not substantially increase the potential risk of $\mathrm{P}$ loss from the sediments. This conclusion is in contrast 
with conventionally constructed wetlands: the longer the wetland operation time, the higher the DPS of the wetland. Thus, the P sorption capacity of the wetland decreases with increasing wetland operation time (Craft, 1996). However, the restored YRD wetlands are natural wetlands that are significantly different from artificially constructed wetlands in three aspects. First, the external P load to the YRD wetlands is significantly lower than that of constructed wetlands. The external $P$ load was calculated to be $8-63 \mathrm{mg} \mathrm{m}^{-2} \mathrm{a}^{-1}$ on the basis of water inflows and P concentration of the water (Cui et al., 2009). In comparison, the external $\mathrm{P}$ load from an artificially constructed wetland ranged between 45-75 $\mathrm{g} \mathrm{m}^{-2} \mathrm{a}^{-1}$. (Vymazal, 2007; Pietro and Ivanoff, 2015). Second, vegetation started to colonize quickly after wetland restoration and the newly emerged macrophyte communities significantly absorbed $\mathrm{P}$ from the wetlands. The vegetation in the restored wetlands is collected every year, thus significantly decreasing $\mathrm{P}$ load to the wetlands (Cui et al., 2009). Finally, the wetland restoration increased plant growth and thereby enhanced organic matter content. In association with organic matter, microorganism will increase, along with soil development. The clay, $\mathrm{Mg}$ and surface $\mathrm{Fe}_{\mathrm{ox}}$ contents also increase with soil development (Table 1). The combined effects of these processes is that the $P$ retention capacity in the YRD significantly increased with the time since restoration, which is contrary to the hypothesis of decreasing storage of $\mathrm{P}$ with increasing restoration time (as found for constructed wetlands). However, it is also necessary to pay attention to the changes in $\mathrm{P}$ load and risk of $\mathrm{P}$ release after the long-term operation of restored natural wetlands to reduce the risk of water eutrophication.

As for coastal wetland restoration, we recommended bringing freshwater into degrade wetlands to improve plant growth. After initiating the plant communities, it is necessary to remove plants from the wetlands to obtain a higher efficiency of nutrient retention. In conjunction with the plant communities, soil development will enhance $P$ storage.

\section{Conclusions}

This study showed that P storage capacity increased with increasing time since wetland restoration while the risk of losing (releasing) $\mathrm{P}$ from the sediments decreased with increasing time in the YRD. Therefore, coastal wetlands restoration is recommended for $\mathrm{P}$ reduction within the coastal zone.

The YRD is located at the intersection of land and sea. The upper reaches of the Yellow River have increased the P load to the wetlands, and ultimately to the Bohai Sea. The offshore water is affected by extra P load, leading to the occurrence of eutrophication of the Bohai Sea. In July 2018, the Ministry of Ecology and Environment of China launched the Action Plan for the Comprehensive Management of the Bohai Sea. The focus of the plan is to carry out the control of land-based pollution, and large rivers (such as the Yellow River) are key pathways through which terrestrial pollutants enter the sea. There are large areas of original and restored wetlands in the Yellow River estuary. We recommended that coastal wetlands be utilized to reduce upstream $\mathrm{P}$ pollution to the Bohai Sea to maintain a P balance in the land-wetlandoffshore watershed.

\section{Declaration of competing interest}

The authors declare that they have no known competing financial interests or personal relationships that could have appeared to influence the work reported in this paper.

\section{Acknowledgements}

This research was co-supported by the National Natural Science Foundation of China (41573120, U1806215), the Key Deployment Project of Chinese Academy of Sciences (KFZD-SW-112), and the Science and Technology Service Network Initiative (KFJ-STS-ZDTP- 


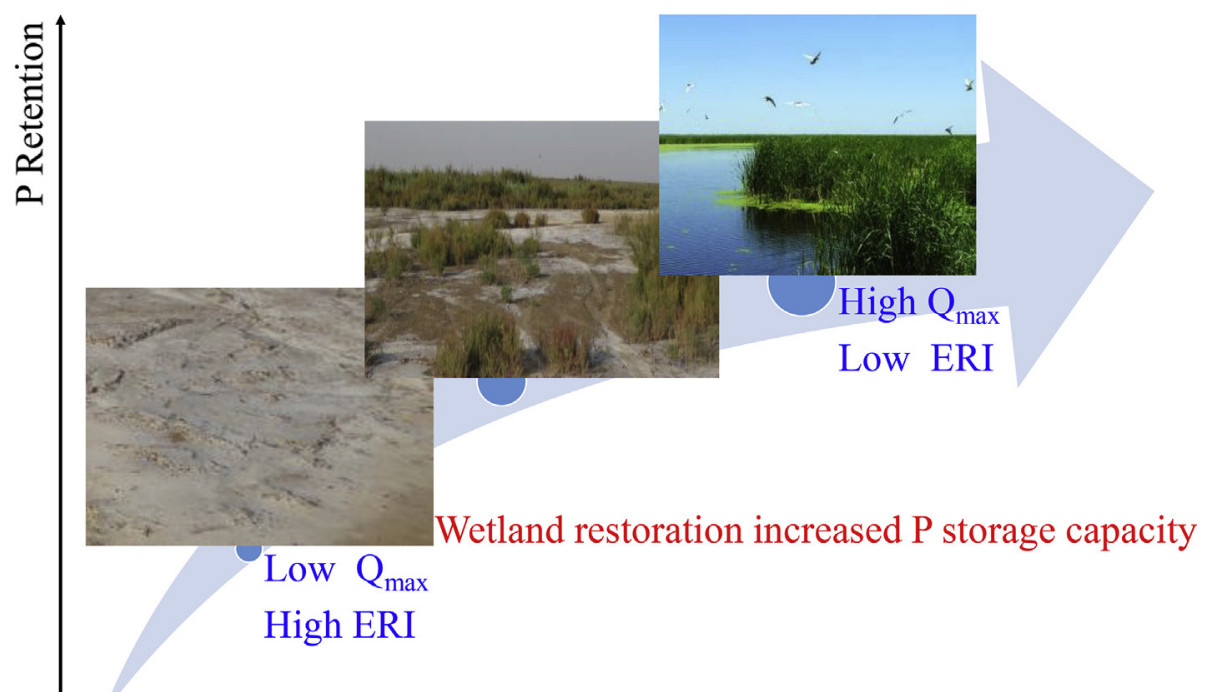

\section{Restoration Time}

Fig. 4. Enhanced phosphorus storage capacity of sediments by coastal wetland restoration in Yellow River Delta, China. (For interpretation of the references to color in this figure legend, the reader is referred to the Web version of this article.)

023).

\section{References}

Ann, Y., Reddy, K., Delfino, J., 1999. Influence of chemical amendments on phosphorus immobilization in soils from a constructed wetland. Ecol. Eng. 14, 157-167.

Antoniadis, V., Koliniati, R., Efstratiou, E., Golia, E., Petropoulos, S., 2016. Effect of soils with varying degree of weathering and $\mathrm{pH}$ values on phosphorus sorption. Catena 139, 214-219.

Bache, B., Williams, E., 1971. A phosphate sorption index for soils. J. Soil Sci. 22, 289-301.

Bai, J., Xiao, R., Zhang, K., Gao, H., 2012. Arsenic and heavy metal pollution in wetland soils from tidal freshwater and salt marshes before and after the flow-sediment regulation regime in the Yellow River Delta, China. J. Hydrol. 450, 244-253.

Bai, J., Ye, X., Jia, J., Zhang, G., Zhao, Q., Cui, B., Liu, X., 2017. Phosphorus sorptiondesorption and effects of temperature, $\mathrm{pH}$ and salinity on phosphorus sorption in marsh soils from coastal wetlands with different flooding conditions. Chemosphere $188,677-688$.

Bai, J., Yu, L., Ye, X., Yu, Z., Guan, Y., Li, X., Cui, B., Liu, X., 2019a. Organic phosphorus mineralization characteristics in sediments from the coastal salt marshes of a Chinese delta under simulated tidal cycles. J. Soils Sediments 1-11.

Bai, J., Yu, Z., Yu, L., Wang, D., Guan, Y., Liu, X., Gu, C., Cui, B., 2019b. In-situ organic phosphorus mineralization in sediments in coastal wetlands with different flooding periods in the Yellow River Delta, China. Sci. Total Environ. 682, 417-425.

Barrow, N., 1978. The description of phosphate sorption curves. J. Soil Sci. 29, 447-462.

Bertrand, I., Holloway, R., Armstrong, R., McLaughlin, M., 2003. Chemical characteristics of phosphorus in alkaline soils from southern Australia. Soil Res. 41, 61-76.

Chen, C., Xu, X., Deng, W., 2014. Characteristics of phosphorus sorption on surface sediments of Dianchi Lake. Acta Sci. Circumstantiae 34, 3065-3075 (In Chinese with English abstract).

Craft, C., 1996. Dynamics of nitrogen and phosphorus retention during wetland ecosystem succession. Wetl. Ecol. Manag. 4, 177-187.

Cui, B., Yang, Q., Yang, Z., Zhang, K., 2009. Evaluating the ecological performance of wetland restoration in the Yellow River Delta, China. Ecol. Eng. 35, 1090-1103.

DeLaune, R.D., Reddy, K.R., 2008. Biogeochemistry of Wetlands: Science and Applications. CRC press, Taylor and Francis Group, Boca Raton.

Dunne, E.J., Reddy, R., Clark, M.W., 2006. Biogeochemical indices of phosphorus retention and release by wetland soils and adjacent stream sediments. Wetlands 26 , 1026-1041.

Gao, D., Chen, G., Li, X., Lin, X., Zeng, C., 2018. Reclamation culture alters sediment phosphorus speciation and ecological risk in coastal zone of southeastern China. Clean. - Soil, Air, Water 46, 1700495.

Guppy, C.N., Menzies, N., Moody, P.W., Blamey, F., 2005. Competitive sorption reactions between phosphorus and organic matter in soil: a review. Soil Res. 43, 189-202.

Huang, Q., Wang, Z., Wang, D., Wang, C., Ma, M., 2004. Phosphorus sorption capacity of the surface sediment in the Lake Taihu and risk assessment of phosphorus release. J. Lake Sci. 16, 97-104 (In Chinese with English abstract).

Ige, D., Akinremi, O., Flaten, D., 2005a. Environmental index for estimating the risk of phosphorus loss in calcareous soils of Manitoba. J. Environ. Qual. 34, 1944-1951.

Ige, D., Akinremi, O., Flaten, D., Ajiboye, B., Kashem, M., 2005b. Phosphorus sorption capacity of alkaline Manitoba soils and its relationship to soil properties. Can. J. Soil Sci. $85,417-426$.

Jin, X., Wang, S., Bu, Q., Wu, F., 2006. Laboratory experiments on phosphorous release from the sediments of 9 lakes in the middle and lower reaches of Yangtze River region, China. Water. Air. Soil. Poll. 176, 233-251.

Lin, C., Wang, Z., He, M., Li, Y., Liu, R., Yang, Z., 2009. Phosphorus sorption and fraction characteristics in the upper, middle and low reach sediments of the Daliao river systems, China. J. Hazard Mater. 170, 278-285.

Liu, M., Hou, L., Xu, S., Ou, D., Yang, Y., Zhang, B., Liu, Q., 2002. Sorption of phosphate on tidal flat surface sediments from the Yangtze Estuary. Environ. Geol. 42, 657-665.

Lu, S., Wang, P., Wang, D., Chen, J., 2011. Phosphorus sorption capacity of the sediment in six lakes of Beijing and risk of potential phosphorus release. China Environ. Sci. 31, 1836-1841.

Lu, Q., Bai, J., Zhang, G., Zhao, Q., Wu, J., 2018. Spatial and seasonal distribution of carbon, nitrogen, phosphorus, and sulfur and their ecological stoichiometry in wetland soils along a water and salt gradient in the Yellow River Delta, China. Phys. Chem. Earth 104, 9-17.

Murphy, J., Riley, J.P., 1962. A modified single solution method for the determination of phosphate in natural waters. Anal. Chim. Acta 27, 31-36.

Nair, V.D., 2014. Soil phosphorus saturation ratio for risk assessment in land use systems. Front. Env. Sci. 2, 6.

Nair, V.D., Reddy, K.R., 2013. Phosphorus sorption and desorption in wetland soils. In: DeLaune, R.D., Reddy, K.R., Richardson, C.J., Megonigal, J.P. (Eds.), Methods in Biogeochemistry of Wetlands. Soil Science Society of America, Madison, WI (USA).

Pant, H., Reddy, K., 2001. Phosphorus sorption characteristics of estuarine sediments under different redox conditions. J. Environ. Qual. 30, 1474-1480.

Pietro, K.C., Ivanoff, D., 2015. Comparison of long-term phosphorus removal performance of two large-scale constructed wetlands in South Florida, USA. Ecol. Eng. 79, $143-157$.

Reddy, K., Kadlec, R., Flaig, E., Gale, P., 1999. Phosphorus retention in streams and wetlands: a review. Crit. Rev. Environ. Sci. Technol. 29, 83-146.

Reddy, K.R., Newman, S., Osborne, T., White, J., Fitz, H., 2011. Phosphorous cycling in the greater Everglades ecosystem: legacy phosphorous implications for management and restoration. Crit. Rev. Environ. Sci. Technol. 41, 149-186.

Saito, Y., Yang, Z., Hori, K., 2001. The Huanghe (Yellow River) and Changjiang (Yangtze River) deltas: a review on their characteristics, evolution and sediment discharge during the Holocene. Geomorphology 41, 219-231.

Schindler, D.W., Hecky, R., Findlay, D., Stainton, M., Parker, B., Paterson, M., Beaty, K., Lyng, M., Kasian, S., 2008. Eutrophication of lakes cannot be controlled by reducing nitrogen input: results of a 37-year whole-ecosystem experiment. Proc. Natl. Acad. Sci. 105, 11254-11258.

Sekhon, B.S., Bhumbla, D.K., Sencindiver, J., McDonald, L.M., 2014. Using soil survey data for series-level environmental phosphorus risk assessment. Enviro. Earth Sci. 72 , 2345-2356.

Shao, X., Liang, X., Wu, M., Gu, B., Li, W., Sheng, X., Wang, S., 2014. Influences of sediment properties and macrophytes on phosphorous speciation in the intertidal marsh. Environ. Sci. Pollut. Res. 21, 10432-10441.

Smith, V.H., Schindler, D.W., 2009. Eutrophication science: where do we go from here? Trends Ecol. Evol. 24, 201-207.

Strokal, M., Yang, H., Zhang, Y., Kroeze, C., Li, L., Luan, S., Wang, H., Yang, S., Zhang, Y., 2014. Increasing eutrophication in the coastal seas of China from 1970 to 2050. Mar. Pollut. Bull. 85, 123-140.

Stumm, W., 1992. Chemistry of the Solid-Water Interface: Processes at the Mineral-Water and Particle-Water Interface in Natural Systems. John Wiley \& Son Inc.

Sundareshwar, P., Morris, J., Koepfler, E., Fornwalt, B., 2003. Phosphorus limitation of coastal ecosystem processes. Science 299, 563-565.

Vymazal, J., 2007. Removal of nutrients in various types of constructed wetlands. Sci. 
Total Environ. 380, 48-65.

Wang, J., Pant, H.K., 2010. Phosphorus sorption characteristics of the Bronx River bed sediments. Chem. Speciat. Bioavailab. 22, 171-181.

Wang, S., Jin, X., Pang, Y., Zhao, H., Zhou, X., Wu, F., 2005. Phosphorus fractions and phosphate sorption characteristics in relation to the sediment compositions of shallow lakes in the middle and lower reaches of Yangtze River region, China. J. Colloid Interface Sci. 289, 339-346.

Wang, M., Qi, S., Zhang, X., 2012. Wetland loss and degradation in the Yellow River delta, shandong province of China. Enviro. Earth Sci. 67, 185-188.

Xu, G., Shao, H.B., Sun, J.N., Chang, S.X., 2012. Phosphorus fractions and profile distribution in newly formed wetland soils along a salinity gradient in the Yellow River Delta in China. J. Plant Nutr. Soil Sci. 175, 721-728.

Yoo, J.-H., Ro, H.-M., Choi, W.-J., Yoo, S.-H., Han, K.-H., 2006. Phosphorus sorption and removal by sediments of a constructed marsh in Korea. Ecol. Eng. 27, 109-117.

Yu, J., Zhan, C., Li, Y., Zhou, D., Fu, Y., Chu, X., Xing, Q., Han, G., Wang, G., Guan, B., 2016. Distribution of carbon, nitrogen and phosphorus in coastal wetland soil related land use in the Modern Yellow River Delta. Sci. Rep. 6, 37940.

Zhang, R., Wu, F., Liu, C., Fu, P., Li, W., Wang, L., Liao, H., Guo, J., 2008. Characteristics of organic phosphorus fractions in different trophic sediments of lakes from the middle and lower reaches of Yangtze River region and Southwestern Plateau, China. Environ. Pollut. 152, 366-372.

Zhou, A., Tang, H., Wang, D., 2005. Phosphorus sorption on natural sediments: modeling and effects of $\mathrm{pH}$ and sediment composition. Water Res. 39, 1245-1254.

Zou, P., Fu, J., Cao, Z., 2011. Chronosequence of paddy soils and phosphorus sorption-desorption properties. J. Soils Sediments 11, 249-259. 